\title{
Interfacial Tension between Molten Iron and $\mathrm{CaO}_{-} \mathrm{SiO}_{2}$ Based Fluxes* $^{*}$
}

\author{
Haiping SUN, Kunihiko NAKASHIMA and Katsumi MORI
}

Department of Materials Science and Engineering, Kyushu University, Hakozaki, Higashi-ku, Fukuoka, Fukuoka-ken, 812 Japan.

(Received on June 26, 1996; accepted in final form on September 9, 1996)

Flux-metal interfacial tension has been examined by $X$-ray photography of a metal drop melted in a molten flux. The experiments were carried out at $1580^{\circ} \mathrm{C}$ using a zirconia crucible with low solubility in the fluxes. The systems used in the investigation were as follows:

Metal phase: $\mathrm{Fe}-\mathrm{O}$ alloy, oxygen content in the alloys varied from 0.002 to 0.070 mass\%.

Flux phase: Ternary system: $\mathrm{CaO}-\mathrm{SiO}_{2}-\mathrm{M}_{x}(\mathrm{~F}, \mathrm{O})_{y}$, where $\mathrm{M}_{x}(\mathrm{~F}, \mathrm{O})_{y}$ represents $\mathrm{NaF}, \mathrm{CaF}_{2}, \mathrm{Al}_{2} \mathrm{O}_{3}, \mathrm{Na}_{2} \mathrm{O}$, $\mathrm{MgO}, \mathrm{Li}_{2} \mathrm{O}$ or $\mathrm{ZrO}_{2}$ and concentrations varied from 2 to 40 mass\%. Multicomponent system: $\mathrm{CaO}-\mathrm{SiO}_{2}-\mathrm{Al}_{2} \mathrm{O}_{3}-\mathrm{Fe}_{2} \mathrm{O}_{3}-\mathrm{Na}_{2} \mathrm{O}-\mathrm{NaF}-\mathrm{CaF}_{2}-\mathrm{MgO}-\mathrm{Li}_{2} \mathrm{O}-\mathrm{ZrO}_{2}$.

The interfacial tension was observed to increase with increasing $\mathrm{NaF}_{2} \mathrm{CaF}_{2}, \mathrm{Na}_{2} \mathrm{O}, \mathrm{MgO}$ or $\mathrm{Li}_{2} \mathrm{O}$ contents, while only minor changes in the values were observed with varying $\mathrm{Al}_{2} \mathrm{O}_{3}$ or $\mathrm{ZrO}_{2}$ contents in $\mathrm{CaO}-\mathrm{SiO}_{2}$ or $\mathrm{CaO}-\mathrm{SiO}_{2}-\mathrm{Al}_{2} \mathrm{O}_{3}$ systems. The interfacial tensions between flux and molten iron decreased with increasing oxygen activity in iron,

$$
\gamma=\gamma_{0}-0.324 \ln \left(1+116 a_{0}\right)
$$

KEY WORDS: interfacial tension; flux; liquid iron; continuous casting; sessile drop.

\section{Introduction}

Interfacial tension between flux and liquid iron is an important property in the production of higher quality steel since low interfacial tension values increase the likelihood for flux entrainment at a flux-metal interface resulting in liquid slag entrapment in the metal phase and eventually to a product defect. Alternatively, if the interfacial tension is high, gaseous bubbles generated in the metal phase during solidification can be easily jammed at flux-metal interface, and these bubbles also lead to a surface defect of the product. In the process of continuous casting, the flux-metal interfacial tension can affect the formation of (a) the initial solidification at the meniscus level, and (b) a flux film between the mould and slab. In order to interpret various phenomena occurring in casting processes, numerous studies have been carried out on the subject over the last several decades. However, there is a considerable disagreement between the measured values, because of flux contamination due to (i) the dissolution of the crucible materials into fluxes and (ii) the difficulties in controlling the oxygen content in the metal resulting from the reaction between slag and molten iron. In the present study, the effect of (i) component in the flux was investigated using a zirconia crucible since $\mathrm{ZrO}_{2}$ has an insignificant effect on the interfacial tension as will be mentioned later to Fig. 10 and also, the contents of $\mathrm{ZrO}_{2}$ dissolved into the flux within the duration of the measurement are rather lower compared with those of other commercial crucible materials, and (ii) oxygen contents on the interfacial tension were examined.

\section{Experimental}

The experiments were performed using the $\mathrm{X}$-ray sessile drop technique at $1580^{\circ} \mathrm{C}$. The metal and flux system were contained in zirconia crucibles resting in an electrical resistance furnace under an argon atmosphere. An X-ray unit was employed to determine the shape of sessile iron drops immersed in the fluxes. Interfacial tensions were obtained from the contour of the droplets on the X-ray pictures by numerical solution of the Young-Laplace equation. The experimental setup, image processing, and numerical resolution are detailed in the previous work. ${ }^{1)}$ Initial iron samples were prepared by melting electrolytic iron $(0.0015$ mass $\%$ C, 0.0009 mass $\%$ $\mathrm{S},<0.0010$ mass $\% \mathrm{P},<0.0005$ mass $\% \mathrm{Si}, 0.0001$ mass $\%$ $\mathrm{Mn}, 0.0001$ mass $\% \mathrm{Cu}, 0.0002$ mass $\% \mathrm{~N}, 0.010$ mass $\%$ $\mathrm{O})$ in an induction furnace under a vacuum atmosphere. Initial fluxes were prepared by premelting mixtures of desired quantities of reagents in a platinum crucible,

\footnotetext{
* This paper was presented in the "International Workshop on Thermophysical Data for the Development of Mathematical Models of Solidification" held at Gifu City from 6-8 October, 1995.
} 
and then crushed to $<12$ mesh after quenching the liquid flux on a stainless plate.

The flux compositions obtained by the chemical analysis of the quenched flux samples after the experiments are shown in Table 1 . The $\mathrm{CaO} / \mathrm{SiO}_{2}$ ratio for these fluxes is close to unity. The composition of the fluxes was varied by adding $\mathrm{NaF}, \mathrm{CaF}_{2}, \mathrm{Al}_{2} \mathrm{O}_{3}, \mathrm{Na}_{2} \mathrm{O}, \mathrm{MgO}$ and $\mathrm{Li}_{2} \mathrm{O}$ from 0 to 40 mass $\%$, respectively. Several percent of $\mathrm{ZrO}_{2}$ was also contained in the final fluxes due to the dissolution of the crucible materials. The density of the molten iron used in these calculations was taken as $6.94 \times 10^{3} \mathrm{~kg} \mathrm{~m}^{-3}$. Table 1 also shows the densities of the molten fluxes used in the measurement of the interfacial tension in the present study. These density values for the molten fluxes were estimated from final flux composition by the regular solution approximation model proposed by Nakajima ${ }^{23}$; it was assumed that the interaction effects of $\mathrm{CaF}_{2}, \mathrm{NaF}$ and $\mathrm{ZrO}_{2}$ with other components in the flux were negligible. The molar volumes of $\mathrm{NaF}$ provided by Bloom and Burrows, ${ }^{3)}$ and those of $\mathrm{ZrO}_{2}$ from the data obtained by Matsuyama ${ }^{4)}$ for the $\mathrm{CaO}-\mathrm{SiO}_{2}-\mathrm{Al}_{2} \mathrm{O}_{3}-\mathrm{Na}_{2} \mathrm{O}-\mathrm{F}^{-}-\mathrm{Li}_{2} \mathrm{O}-\mathrm{ZrO}_{2}$ system were used in the density determination. From the measurements of the interfacial tension as a function of time, the tension was found to be independent of time after molten fluxes were in contact with the iron droplet for 10 min. The average of several measured values after 10 min was used as the interfacial tension of the measured system.

\section{Results and Discussion}

\subsection{Effect of Oxygen in Molten Iron}

The interfacial tension is markedly reduced by the oxygen in the molten iron due to its strongly surface active nature. In the present study, a graphite protection crucible was used to reduce any oxygen presented in the atmosphere during the measurements, consequently great attention was paid in the preparation of

Table 1. Flux compositions and interfacial tensions between the fluxes and molten iron.

\begin{tabular}{|c|c|c|c|c|c|c|c|c|}
\hline \multirow{2}{*}{$\begin{array}{l}\text { Flux } \\
\text { Type }\end{array}$} & \multicolumn{4}{|c|}{ flux compositions } & \multirow{2}{*}{$\begin{array}{l}\text { oxygen activity } \\
\text { in metal, } a_{0}\end{array}$} & \multirow{2}{*}{$\begin{array}{c}\text { flux } \\
\text { density } \\
10^{3} \mathrm{~kg} \mathrm{~m}^{-3}\end{array}$} & \multicolumn{2}{|c|}{ interfacial tensior } \\
\hline & $\mathrm{CaO}$ & $\begin{array}{l}\mathrm{SiO}_{2} \\
\text { mass \% }\end{array}$ & $\mathrm{ZrO}_{2}$ & additions & & & $\begin{array}{c}\gamma \\
N^{-1}\end{array}$ & $\begin{array}{c}\gamma_{0} \\
\mathrm{~N} \mathrm{~m}^{-1}\end{array}$ \\
\hline$A-1$ & 47.1 & 45.4 & 6.7 & & 0.0056 & 2.541 & 1.314 & 1.476 \\
\hline $\begin{array}{l}\text { A-2 } \\
\text { A-3 }\end{array}$ & $\begin{array}{l}41.1 \\
36.0\end{array}$ & $\begin{array}{l}38.1 \\
34.8\end{array}$ & $\begin{array}{l}11.8 \\
12.4\end{array}$ & $\begin{array}{l}\mathrm{NaF}: 6.40 \\
\mathrm{NaF}: 15.0\end{array}$ & $\begin{array}{l}0.0023 \\
0.0039\end{array}$ & $\begin{array}{l}2.501 \\
2.393\end{array}$ & $\begin{array}{l}1.362 \\
1.384\end{array}$ & $\begin{array}{l}1.437 \\
1.504\end{array}$ \\
\hline $\begin{array}{l}\text { B-1 } \\
\text { B-2 }\end{array}$ & $\begin{array}{l}42.2 \\
36.6\end{array}$ & $\begin{array}{l}38.6 \\
35.3\end{array}$ & $\begin{array}{l}9.4 \\
10.8\end{array}$ & $\begin{array}{l}\mathrm{CaF}_{2}: 7.60 \\
\mathrm{CaF}_{2}: 15.8\end{array}$ & & & & $\begin{array}{l}1.496 \\
1.515\end{array}$ \\
\hline $\begin{array}{l}C-1 \\
C-2 \\
C-3 \\
C-4\end{array}$ & $\begin{array}{l}43.0 \\
38.6 \\
34.4 \\
29.5\end{array}$ & $\begin{array}{l}41.5 \\
38.4 \\
33.0 \\
28.5\end{array}$ & $\begin{array}{l}4.5 \\
1.4 \\
1.6\end{array}$ & $\begin{array}{l}\mathrm{Al}_{2} \mathrm{O}_{3}: 9.60 \\
\mathrm{Al}_{2} \mathrm{O}_{3}: 19.2 \\
\mathrm{Al}_{2} \mathrm{O}_{3}: 29.0 \\
\mathrm{Al}_{2} \mathrm{O}_{3}: 41.7\end{array}$ & & $\begin{array}{l}2.593 \\
2.637 \\
2.721 \\
2.805\end{array}$ & $\begin{array}{l}1.388 \\
1.315 \\
1.257 \\
1.222\end{array}$ & $\begin{array}{l}1.481 \\
1.447 \\
1.416 \\
1.441\end{array}$ \\
\hline $\begin{array}{l}\text { D-1 } \\
\text { D-2 } \\
\text { D-3 }\end{array}$ & $\begin{array}{l}37.2 \\
41.8 \\
35.9\end{array}$ & $\begin{array}{l}40.6 \\
41.7 \\
36.0\end{array}$ & $\begin{array}{l}8.8 \\
4.7 \\
6.1\end{array}$ & $\begin{array}{l}\mathrm{Na}_{2} \mathrm{O}: 3.50 \\
\mathrm{Na}_{2} \mathrm{O}: 9.20 \\
\mathrm{Na}_{2} \mathrm{O}: 17.5\end{array}$ & $\begin{array}{l}0.0108 \\
0.0021 \\
0.0048\end{array}$ & $\begin{array}{l}2.517 \\
2.455 \\
2.406\end{array}$ & $\begin{array}{l}1.331 \\
1.523 \\
1.395\end{array}$ & $\begin{array}{l}1.594 \\
1.594 \\
1.539\end{array}$ \\
\hline $\begin{array}{l}\text { E-1 } \\
\text { E-2 }\end{array}$ & $\begin{array}{l}42.1 \\
36.7\end{array}$ & $\begin{array}{l}40.7 \\
35.9\end{array}$ & $\begin{array}{l}3.1 \\
4.7\end{array}$ & $\begin{array}{l}\text { MgO:9.4 } \\
\text { MgO:17.8 }\end{array}$ & $\begin{array}{l}0.0035 \\
0.0024\end{array}$ & $\begin{array}{l}2.563 \\
2.618\end{array}$ & $\begin{array}{l}1.487 \\
1.570\end{array}$ & $\begin{array}{l}1.599 \\
1.651\end{array}$ \\
\hline $\begin{array}{l}\text { G-1 } \\
\text { G-2 } \\
\text { G-3 } \\
\text { G-4 } \\
\text { G-5 }\end{array}$ & $\begin{array}{l}45.0 \\
41.6 \\
40.2 \\
42.8 \\
47.7\end{array}$ & $\begin{array}{l}43.0 \\
42.0 \\
42.6 \\
42.2 \\
47.4\end{array}$ & $\begin{array}{l}6.7 \\
8.6 \\
8.1 \\
7.7 \\
8.0\end{array}$ & $\begin{array}{l}\mathrm{Li}_{2} \mathrm{O}: 1.5 \\
\mathrm{Li}_{2} \mathrm{O}: 4.2 \\
\mathrm{Li}_{2} \mathrm{O}: 8.3 \\
\mathrm{Li}_{2} \mathrm{O}: 1.7 \\
\mathrm{Li}_{2} \mathrm{O}: 4.6\end{array}$ & $\begin{array}{l}0.0042 \\
0.0026 \\
0.0175 \\
0.0035 \\
0.0199\end{array}$ & $\begin{array}{l}2.458 \\
2.482 \\
2.411 \\
2.520 \\
2.475\end{array}$ & $\begin{array}{l}1.445 \\
1.464 \\
1.446 \\
1.485 \\
1.375\end{array}$ & $\begin{array}{l}1.572 \\
1.550 \\
1.805 \\
1.597 \\
1.763\end{array}$ \\
\hline $\begin{array}{l}J-1 \\
J-2 \\
J-3\end{array}$ & $\begin{array}{l}27.6 \\
26.7 \\
25.1\end{array}$ & $\begin{array}{l}27.9 \\
27.0 \\
25.2\end{array}$ & $\begin{array}{l}5.2 \\
9.5 \\
14.2\end{array}$ & $\begin{array}{l}\mathrm{Al}_{2} \mathrm{O}_{3}: 38.6 \\
\mathrm{Al}_{2} \mathrm{O}_{3}: 36.1 \\
\mathrm{Al}_{2} \mathrm{O}_{3}: 34.8\end{array}$ & $\begin{array}{l}0.0051 \\
0.0052 \\
0.0085\end{array}$ & $\begin{array}{l}2.823 \\
2.842 \\
2.876\end{array}$ & $\begin{array}{l}1.166 \\
1.190 \\
1.170\end{array}$ & $\begin{array}{l}1.318 \\
1.343 \\
1.393\end{array}$ \\
\hline
\end{tabular}

the samples for the measurements and the prevention of the oxygen pickup of the iron during the measurements. However, as seen in Table 1, 20-200 ppm of oxygen were contained in the final metal samples. These oxygen levels are considered to be generated from the decomposition of the oxides in the slag and the contamination by air during the flux addition. The interfacial tension is plotted against the oxygen content in Fig. 1. Although it was found that the dependence of the interfacial tension on the oxygen content was not very clear, a decrease in the interfacial tension with increasing oxygen content was obvious for each flux system. This indicates that the interfacial tension obtained in the present study depends not only on the flux composition but also upon the oxygen content in the molten iron. Therefore the effect of the oxygen in the molten iron should be taken into account in order to make clear the flux composition effect on the interfacial tension.

A literature survey shows that many investigations on the oxygen effect ${ }^{5-8)}$ have been carried out since the past several decades, but a numerical relation between interfacial tension and oxygen content has not been established yet. This is because the slag system and composition were not identical and the variation of the interfacial tension with slag composition was not taken into consideration in these studies. In the present study, the effect of oxygen content on the interfacial tension between flux and molten iron was investigated using $35 \mathrm{CaO}-35 \mathrm{SiO}_{2}-30 \mathrm{Al}_{2} \mathrm{O}_{3}$ flux and pure molten iron in an alumina crucible. The oxygen content in the molten iron was controlled by adding a certain amount of $\mathrm{FeO}$ $(0-12.1 \mathrm{mass} \%)$ into the flux. The observed interfacial tensions, oxygen contents, and estimated flux densities are given in Table 2 . The oxygen activities referred to the infinite dilution for oxygen in metal based on the Henrian law were calculated from oxygen contents and the interaction parameter $e_{0}^{\circ}=-0.17,{ }^{9)}$ and were also given in the table. The relation between interfacial tension and oxygen content in metal is shown in Fig. 2. A decrease in the interfacial tension with increasing the oxygen content was observed.

The relation between surface tension of molten iron

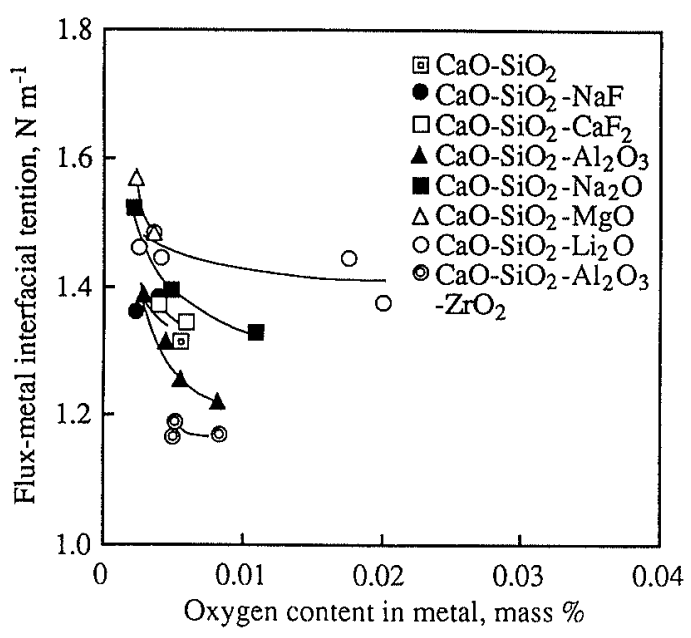

Fig. 1. Interfacial tension $v s$. oxygen content in molten iron at $1580^{\circ} \mathrm{C}$. 
Table 2. Effect of oxygen in metal on the interfacial tension between $35 \mathrm{CaO}-35 \mathrm{SiO}_{2}-30 \mathrm{Al}_{2} \mathrm{O}_{3}+\mathrm{FeO}$ flux and Fe-O metal at $1580^{\circ} \mathrm{C}$.

\begin{tabular}{|c|c|c|c|}
\hline $\begin{array}{l}\text { oxygen } \\
\text { mass\% }\end{array}$ & $a_{0}$ & $\begin{array}{l}\text { flux density } \\
10^{3} \mathrm{~kg} \mathrm{~m}^{-3}\end{array}$ & $\begin{array}{l}\gamma \\
\mathrm{N} \mathrm{m}^{-1}\end{array}$ \\
\hline 0.0055 & 0.0055 & 2.793 & 1.168 \\
\hline 0.0066 & 0.0066 & 2.794 & 1.230 \\
\hline 0.0069 & 0.0069 & 2.795 & 1.180 \\
\hline 0.0073 & 0.0073 & 2.795 & 1.183 \\
\hline 0.0073 & 0.0073 & 2.795 & 1.211 \\
\hline 0.0073 & 0.0073 & 2.795 & 1.223 \\
\hline 0.0081 & 0.0080 & 2.796 & 1.143 \\
\hline 0.0081 & 0.0080 & 2.796 & 1.184 \\
\hline 0.0081 & 0.0081 & 2.796 & 1.218 \\
\hline 0.0085 & 0.0085 & 2.797 & 1.137 \\
\hline 0.0088 & 0.0088 & 2.797 & 1.146 \\
\hline 0.0106 & 0.0106 & 2.799 & 1.152 \\
\hline 0.0130 & 0.0130 & 2.802 & 1.050 \\
\hline 0.0147 & 0.0146 & 2.805 & 1.080 \\
\hline 0.0162 & 0.0161 & 2.806 & 1.081 \\
\hline 0.0181 & 0.0180 & 2.809 & 1.014 \\
\hline 0.0183 & 0.0182 & 2.809 & 0.992 \\
\hline 0.0188 & 0.0186 & 2.810 & 1.015 \\
\hline 0.0197 & 0.0195 & 2.811 & 0.992 \\
\hline 0.0211 & 0.0209 & 2.812 & 0.986 \\
\hline 0.0247 & 0.0244 & 2.817 & 0.931 \\
\hline 0.0270 & 0.0267 & 2.820 & 0.933 \\
\hline 0.0281 & 0.0278 & 2.821 & 0.945 \\
\hline 0.0313 & 0.0309 & 2.825 & 0.884 \\
\hline 0.0333 & 0.0329 & 2.827 & 0.881 \\
\hline 0.0363 & 0.0357 & 2.831 & 0.847 \\
\hline 0.0400 & 0.0393 & 2.836 & 0.798 \\
\hline 0.0410 & 0.0403 & 2.838 & 0.791 \\
\hline 0.0436 & 0.0428 & 2.844 & 0.821 \\
\hline 0.0438 & 0.0430 & 2.846 & 0.847 \\
\hline 0.0443 & 0.0435 & 2.848 & 0.807 \\
\hline 0.0522 & 0.0510 & 2.850 & 0.754 \\
\hline 0.0586 & 0.0572 & 2.858 & 0.709 \\
\hline 0.0598 & 0.0583 & 2.859 & 0.705 \\
\hline 0.0705 & 0.0684 & 2.872 & 0.705 \\
\hline
\end{tabular}

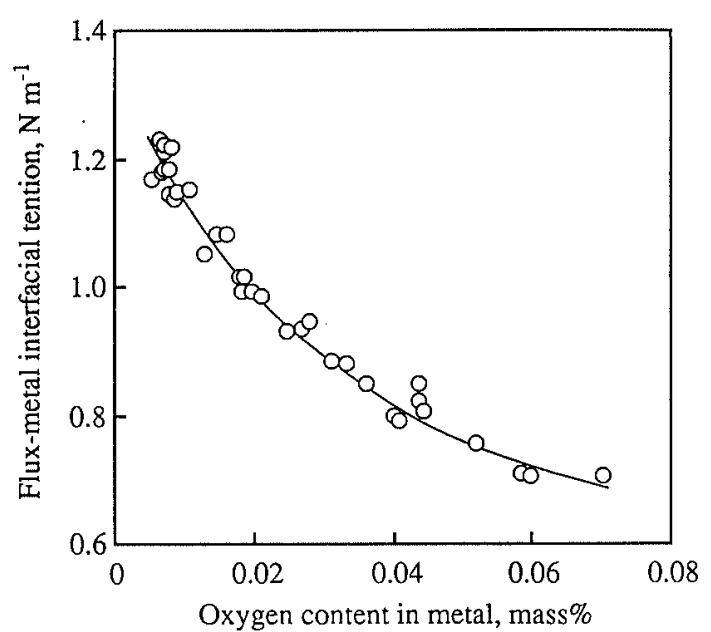

Fig. 2. Dependence of $35 \mathrm{CaO}-35 \mathrm{SiO}_{2}-30 \mathrm{Al}_{2} \mathrm{O}_{3}+\mathrm{FeO}(=0$ 12.1 mass $\%$ ) flux and Fe-O molten iron interfacial tension on oxygen content in molten iron at $1580^{\circ} \mathrm{C}$.

and oxygen content in the melt proposed by Belton ${ }^{10}$ ) indicated that,

$$
\gamma_{0}-\gamma=R T \Gamma^{0} \ln \left(1+K_{\mathrm{o}} a_{\mathrm{o}}\right)
$$

where, $\gamma_{0}$ : the surface tension of the pure liquid, $\mathrm{N} \mathrm{m}^{-1}$,

$\Gamma^{0}$ : the surface excess quantity at full coverage, mol m ${ }^{-2}$

$a_{\mathrm{O}}$ : activity of oxygen in the molten iron, and

$K_{\mathrm{O}}$ : equilibrium constant of oxygen adsorption reaction at surface.

This relation was also observed to be applied to the interfacial tension. ${ }^{1,7)}$ The values of the parameters, $\gamma_{0}$,

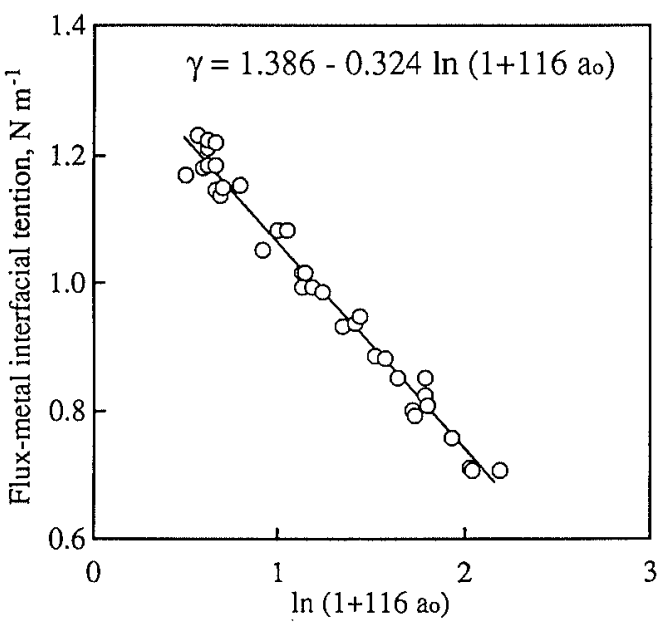

Fig. 3. Measured interfacial tension values at $1580^{\circ} \mathrm{C}$ against oxygen activity based on Eq. (2).

$R T \Gamma^{0}$ and $K_{\mathrm{O}}$ in Eq. (1) for the data presented in Table 2 were determined by an iteration calculation involving several steps: (i) the values of the $\gamma_{0}$ and $R T \Gamma^{0}$ are calculated using a given value of $K_{\mathrm{O}}$ obtained by least squares method, and (ii) then this calculation was repeated by changing the value of $K_{0}$ until the maximum value of the correlation coefficient was obtained. The relation for $35 \mathrm{CaO}-35 \mathrm{SiO}_{2}-30 \mathrm{Al}_{2} \mathrm{O}_{3}$ flux and molten iron at $1580^{\circ} \mathrm{C}$ was found as follows,

$$
\begin{aligned}
& \gamma_{0}-\gamma=0.324 \ln \left(1+116 a_{\mathrm{o}}\right) \\
& \gamma_{0}=1.386 \mathrm{~N} \mathrm{~m}^{-1}
\end{aligned}
$$

Figure 3 shows the measured values plotted against the activity of oxygen, based on Eq. (2).

If the adsorption of oxygen, in the form of ion, at the flux-molten iron interface is a single layer and in most dense configuration, the value of $R T \Gamma^{0}=0.417 \mathrm{~N} \mathrm{~m}^{-1}$ can be calculated from the radius ${ }^{11}$ of oxygen ion $(1.32 \AA)$. If the adsorption of oxygen at the flux-molten iron interface is a single layer of $\mathrm{FeO}$ and in most dense configuration, the value of $R T \Gamma^{0}=0.272 \mathrm{~N} \mathrm{~m}^{-1}$ is obtained from the radii ${ }^{11}$ ) of oxygen (1.32 $\AA$ ) and iron ions $(0.83 \AA)$. The value of $R T T^{0}$ obtained in the present study $\left(0.324 \mathrm{~N} \mathrm{~m}^{-1}\right)$ is between these two values. The values of $R T \Gamma^{0}$ and $K_{\mathrm{O}}$, respectively, reported by Ogino et al. at $1600^{\circ} \mathrm{C},{ }^{12)} \mathrm{Jimbo}$ et al. at $1550^{\circ} \mathrm{C}^{13)}$ and Kasama et al. at $1600^{\circ} \mathrm{C}^{14)}$ for the surface tension of molten iron-oxygen alloy were 0.358 and $210,0.279$ and 140 , and 0.299 and 110 , respectively. The values of $R T \Gamma^{0}$ and $K_{\mathrm{O}}$ for interfacial tension compares reasonably well with those reported for the surface tension.

In the measurement of the interfacial tensions between flux and molten iron, the variation of the oxygen content in the metal phases could not be avoided (Table 1). Assuming that the surface excess quantity at full coverage and equilibrium constant of oxygen adsorption are independent of the flux composition, hypothetical interfacial tensions (where oxygen activity in the molten iron is zero, $\gamma_{0}$ ), were calculated for the fluxes using Eq. (2). The values of $\gamma_{0}$, which is independent on the oxygen content in the melt, is used to examine the effect of flux composition on the interfacial tension 
between the flux and the molten iron. The effect of sulfur was ignored in the present study, since sulfur content in the metal phase $(0.0009$ mass $\%)$ was much lower compared with that of oxygen, and the interfacial tension was less sensitive to sulfur in the metal phase than surface tension was, as seen in the previous results. ${ }^{1,29)}$

\subsection{Interfacial Tension for Ternary System \\ Effect of $\mathrm{NaF}$}

The results on the influence of $\mathrm{NaF}$ content in the flux are shown in Fig. 4. The $\mathrm{NaF}$ content in the $\mathrm{CaO}-\mathrm{SiO}_{2}$ flux was varied from 0 to 20 mass $\%$. The solid circles show the measured values of the interfacial tension and the vertical bars show the standard deviation of the measurement. The values given in the brackets are the oxygen content where the interfacial tensions were measured. The open circles are the values corrected with respect to the oxygen content in the iron based on Eq. (2). A slight increase in the interfacial tension was observed as the NaF content in the flux increases. The results for the $\mathrm{CaO}-\mathrm{Al}_{2} \mathrm{O}_{3}$ flux reported by Evseev and Filippov, ${ }^{15)}$ which show a strong effect of $\mathrm{NaF}$, are also presented in the figure to provide a comparison with the present results for the $\mathrm{CaO}-\mathrm{SiO}_{2}$ flux.

\section{Effect of $\mathrm{CaF}_{2}$}

The variation of the interfacial tension with $\mathrm{CaF}_{2}$ content in the $\mathrm{CaO}-\mathrm{SiO}_{2}$ flux is shown in Fig. 5. A slight increase in the interfacial tension was observed as the $\mathrm{CaF}_{2}$ content in the flux increases similar to that of $\mathrm{NaF}$. The same trend was also shown in the results due to Shinozaki et al. ${ }^{16)}$ for $\mathrm{CaO}-\mathrm{SiO}_{2}-\mathrm{Al}_{2} \mathrm{O}_{3}$ flux using alumina or magnesia crucibles $\left(a_{\mathrm{O}}=0.0010-0.0031\right)$. The values obtained by Gaye et $a{ }^{1}{ }^{17)}$ for this flux are also presented in the figure. Their results are consistent with those of the present work when the higher oxygen contents of the metal in their measurement $\left(a_{0}=0.0047-\right.$ 0.0186 ) are taken into account. The results due to Ogino et al. using a slag lens method ${ }^{18)}$ for $\mathrm{CaO}-\mathrm{Al}_{2} \mathrm{O}_{3}$ flux. also show an increasing trend with $\mathrm{CaF}_{2}$ addition. The similar trends observed by the additions of $\mathrm{NaF}$ and

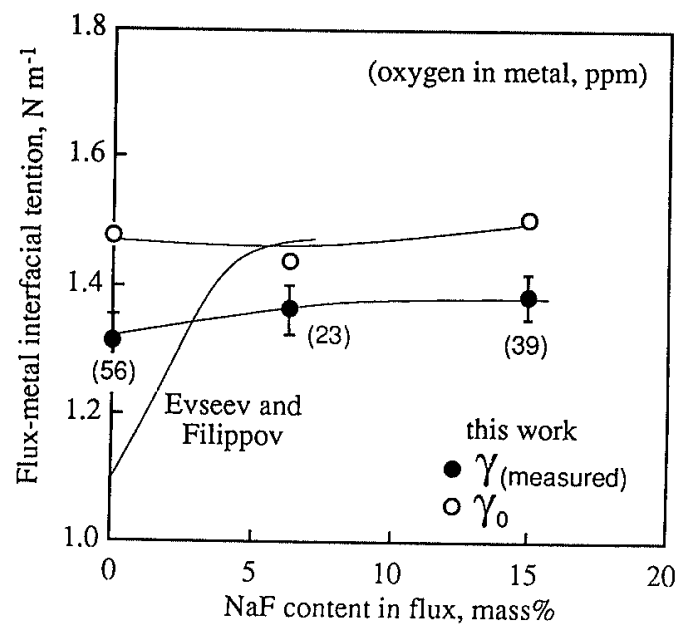

Fig. 4. Effect of NaF in flux on the interfacial tension between liquid iron and flux.

this work: $\mathrm{CaO}-\mathrm{SiO}_{2}$ flux, zirconia crucible, $1580^{\circ} \mathrm{C}$ Evseev and Filippov: $\mathrm{CaO}-\mathrm{Al}_{2} \mathrm{O}_{3}$ flux
$\mathrm{CaF}_{2}$ to the flux are considered to be due to the weak interaction between fluorine and the molten iron.

Effect of $\mathrm{Al}_{2} \mathrm{O}_{3}$

Figure 6 shows the influence of $\mathrm{Al}_{2} \mathrm{O}_{3}$ content in the $\mathrm{CaO}-\mathrm{SiO}_{2}$ flux on the interfacial tension. The measured interfacial tension was increased when $10 \% \mathrm{Al}_{2} \mathrm{O}_{3}$ was added to the flux but decreased with further increasing $\mathrm{Al}_{2} \mathrm{O}_{3}$ content, and remained unchanged when $\mathrm{Al}_{2} \mathrm{O}_{3}$ was more than $30 \%$. This complicated behavior is considered to be caused by the variation of the oxygen content in the melt. As shown in the figure, $\gamma_{0}$, was slightly decreased with addition of $\mathrm{Al}_{2} \mathrm{O}_{3}$ to the flux. The values measured by $\mathrm{El}$ Gammal and Stracke ${ }^{19)}$ using drop weight method are lower than those in the present study. This is not surprising since the metal sulfur

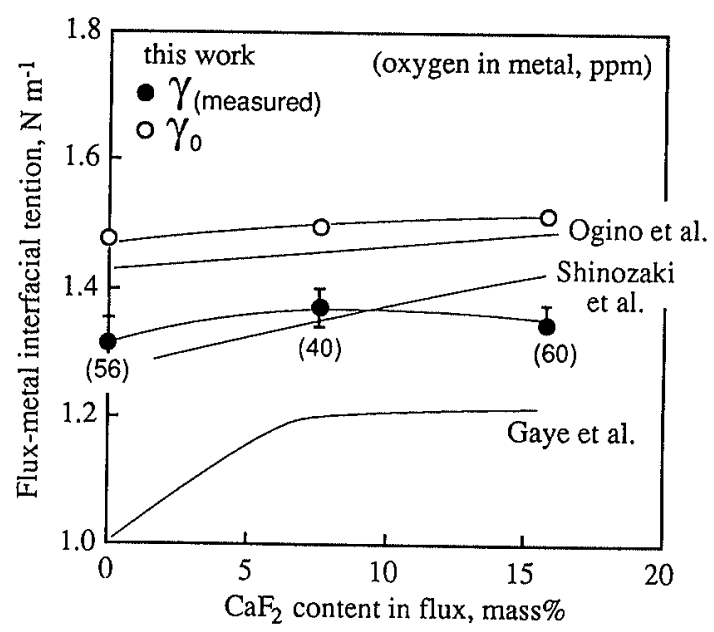

Fig. 5. Effect of $\mathrm{CaF}_{2}$ in flux on the interfacial tension between liquid iron and flux.

this work: $\mathrm{CaO}-\mathrm{SiO}_{2}$ flux, zirconia crucible, $1580^{\circ} \mathrm{C}$ Ogino et al:: $\mathrm{CaO}-\mathrm{Al}_{2} \mathrm{O}_{3}$ flux lens method, $1600^{\circ} \mathrm{C}$ Shinozaki et al:: $\mathrm{CaO}-\mathrm{SiO}_{2}-\mathrm{Al}_{2} \mathrm{O}_{3}$ flux, alumina or magnesia crucible, $1600^{\circ} \mathrm{C}$

Gaye et al:: $\mathrm{CaO}-\mathrm{SiO}_{2}-\mathrm{Al}_{2} \mathrm{O}_{3}$ flux, alumina crucible, $1600^{\circ} \mathrm{C}$

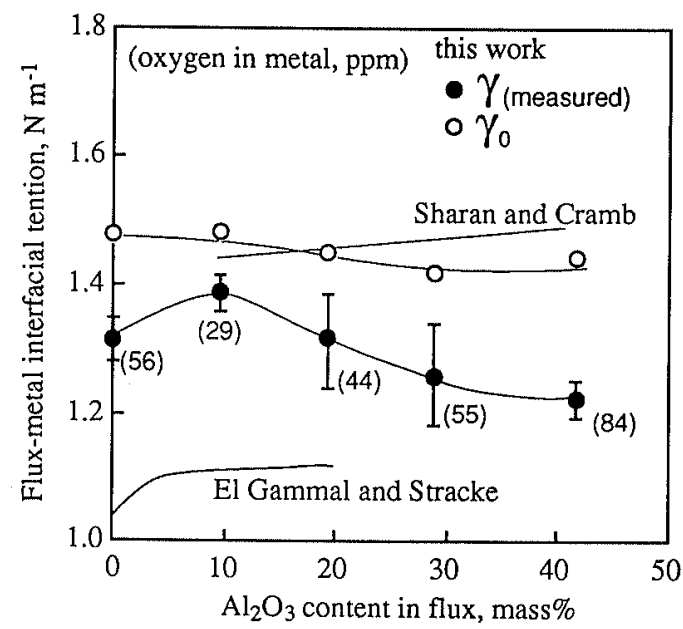

Fig. 6. Effect of $\mathrm{Al}_{2} \mathrm{O}_{3}$ in flux on the interfacial tension between liquid iron and flux.

this work: $\mathrm{CaO}-\mathrm{SiO}_{2}$ flux, zirconia crucible, $1580^{\circ} \mathrm{C}$ El Gammal and Stracke: $\mathrm{CaO}-\mathrm{SiO}_{2}-\mathrm{Al}_{2} \mathrm{O}_{3}$ flux, drop weight method, $1570^{\circ} \mathrm{C}$

Sharan and Cramb: $\mathrm{CaO}-\mathrm{SiO}_{2}-\mathrm{Al}_{2} \mathrm{O}_{3}$ flux and $\mathrm{Fe}-20 \% \mathrm{Ni}$ alloy, alumina crucible, $1550^{\circ} \mathrm{C}$ 
content of their measurement was as high as about 0.038 mass $\%$, which was much higher than that of the present study.

\section{Effect of $\mathrm{Na}_{2} \mathrm{O}$}

The influence of $\mathrm{Na}_{2} \mathrm{O}$ content of the flux on the interfacial tension is shown in Fig. 7. An increase in the interfacial tension was observed as the $\mathrm{Na}_{2} \mathrm{O}$ content in the flux increases. This trend is in agreement with the results obtained by Shinozaki et al. ${ }^{16)}$ for $\mathrm{CaO}-\mathrm{SiO}_{2}-$ $\mathrm{Al}_{2} \mathrm{O}_{3}$ flux. However, an opposite trend was obtained in the study of Adachi et al. ${ }^{20}$ ) The values provided by Gaye et al. ${ }^{17)}$ for $\mathrm{CaO}-\mathrm{SiO}_{2}-\mathrm{Al}_{2} \mathrm{O}_{3}$ flux show an increasing trend although they are lower than those of the present study because the oxygen content in their

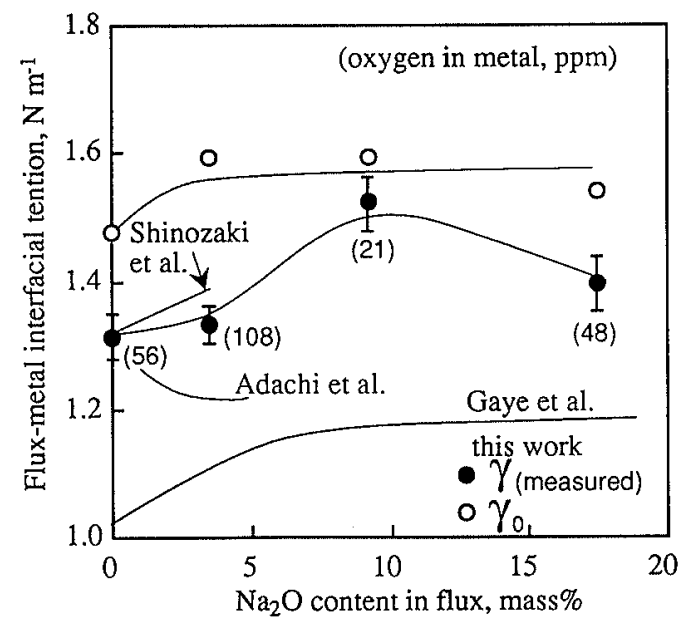

Fig. 7. Effect of $\mathrm{Na}_{2} \mathrm{O}$ in flux on the interfacial tension between liquid iron and flux.

this work: $\mathrm{CaO}-\mathrm{SiO}_{2}$ flux, zirconia crucible, $1580^{\circ} \mathrm{C}$ Shinozaki et al:: $\mathrm{CaO}-\mathrm{SiO}_{2}-\mathrm{Al}_{2} \mathrm{O}_{3}$ flux, magnesia crucible, $1600^{\circ} \mathrm{C}$

Adachi et al:: $\mathrm{CaO}-\mathrm{MgO}-\mathrm{Al}_{2} \mathrm{O}_{3}$ flux, lens method, $1540^{\circ} \mathrm{C}$

Gaye et al: $\mathrm{CaO}-\mathrm{SiO}_{2}-\mathrm{Al}_{2} \mathrm{O}_{3}$ flux, lens method, $1600^{\circ} \mathrm{C}$

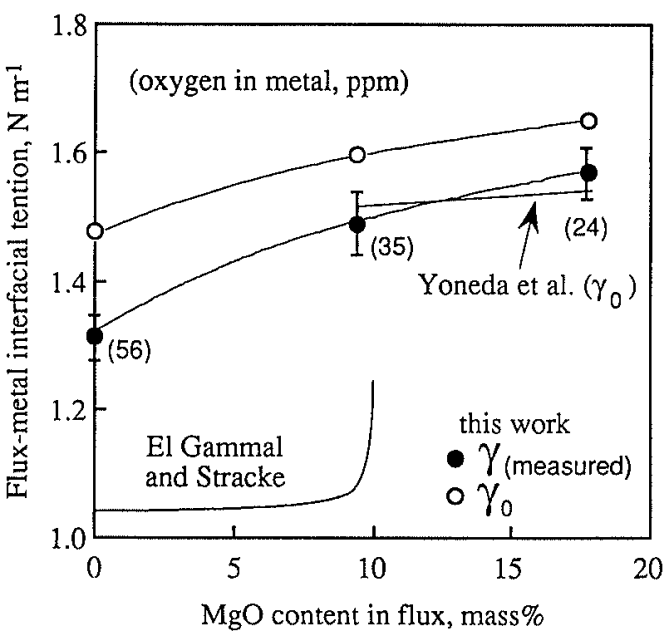

Fig. 8. Effect of MgO in flux on the interfacial tension between liquid iron and flux.

this work: $\mathrm{CaO}-\mathrm{SiO}_{2}$ flux, zirconia crucible, $1580^{\circ} \mathrm{C}$ Yoneda et al: $\mathrm{CaO}-\mathrm{SiO}_{2}$ flux, zirconia crucible, $1580^{\circ} \mathrm{C}$

El Gammal and Stracke: $\mathrm{CaO}-\mathrm{SiO}_{2}-\mathrm{Al}_{2} \mathrm{O}_{3}$ flux, drop weight method, $1570^{\circ} \mathrm{C}$ measurements was relative high.

\section{Effect of $\mathrm{MgO}$}

Figure 8 shows the interfacial tension variation with $\mathrm{MgO}$ content in flux which is similar to that of $\mathrm{Na}_{2} \mathrm{O}$, i.e., an increase in the $\mathrm{MgO}$ content increases the interfacial tension. The $\gamma_{0}$ values for this system measured by Yoneda et al. ${ }^{21)}$ using a zirconia crucible also show the increasing trend with $\mathrm{MgO}$ additions. The lower interfacial tension obtained by El Gammal and Stracke ${ }^{19)}$ in $\mathrm{CaO}-\mathrm{SiO}_{2}-\mathrm{Al}_{2} \mathrm{O}_{3}$ flux where $\mathrm{CaO} / \mathrm{SiO}_{2}=1$ and $\mathrm{Al}_{2} \mathrm{O}_{3}=15 \mathrm{mass} \%$ may be due to the higher sulfur content in their metal.

\section{Effect of $\mathrm{Li}_{2} \mathrm{O}$}

As can be seen from Fig. 9, an increase in the interfacial tension was observed with increasing $\mathrm{Li}_{2} \mathrm{O}$ content in the flux. The decreasing trend with increasing $\mathrm{Li}_{2} \mathrm{O}$ content in the flux by more than $5 \%$ is considered to be due to the higher oxygen content in the melt. The increase of $\gamma_{0}$ with $\mathrm{Li}_{2} \mathrm{O}$ content in the flux was obvious. This agrees with the results of Shinozaki et al. ${ }^{16)}$ for $\mathrm{CaO}$ $\mathrm{SiO}_{2}-\mathrm{Al}_{2} \mathrm{O}_{3}$ flux containing less than 8 mass $\%$ of $\mathrm{Li}_{2} \mathrm{O}$.

Effect of $\mathrm{ZrO}_{2}$

In the investigation of flux containing zirconia, a $\mathrm{CaO}-\mathrm{SiO}_{2}-\mathrm{Al}_{2} \mathrm{O}_{3}$ flux and alumina crucibles were used. The results are presented in Fig. 10. $\gamma$ and $\gamma_{0}$ points at $\mathrm{ZrO}_{2}=0$ mass $\%$ and at $\mathrm{ZrO}_{2}=1.6 \mathrm{mass} \%$ are from $\mathrm{C}-3$ and $\mathrm{C}-4$ fluxes, respectively, and the $\gamma_{0}$ value obtained for $35 \mathrm{CaO}-35 \mathrm{SiO}_{2}-30 \mathrm{Al}_{2} \mathrm{O}_{3}$ as given in Fig. 3 was also shown in Fig. 10 at $\mathrm{ZrO}_{2}=0$ mass\%. Although relatively large scatters were observed in the Fig. 10 for $\gamma_{0}$ values, the interfacial tension slightly decreased with increasing $\mathrm{ZrO}_{2}$ in the content range below 5 mass $\% \mathrm{ZrO}_{2}$ and slightly increased with increasing $\mathrm{ZrO}_{2}$ when flux contains more than 5 mass $\% \mathrm{ZrO}_{2}$. Considering the relatively small effect of $\mathrm{ZrO}_{2}$ on the interfacial tension and the nearly same low level of $\mathrm{ZrO}_{2}$ dissolution in each flux system, $\mathrm{ZrO}_{2}$ dissolution is considered to have a negligible effect on the evaluation of the variation of the interfacial tension with certain component

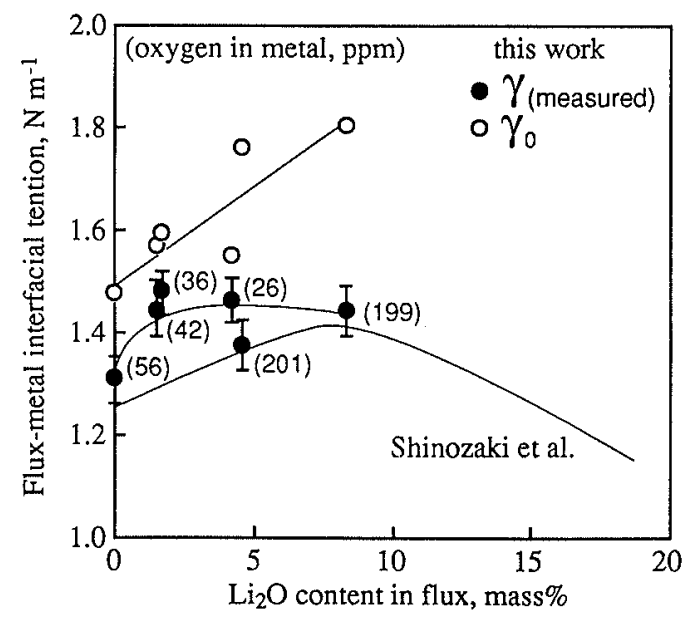

Fig. 9. Effect of $\mathrm{Li}_{2} \mathrm{O}$ in flux on the interfacial tension between liquid iron and flux.

this work: $\mathrm{CaO}-\mathrm{SiO}_{2}$ flux, zirconia crucible, $1580^{\circ} \mathrm{C}$ Shinozaki et al:: $\mathrm{CaO}-\mathrm{SiO}_{2}-\mathrm{Al}_{2} \mathrm{O}_{3}$ flux, magnesia crucible, $1600^{\circ} \mathrm{C}$ 
content in the flux. An insignificant effect of $\mathrm{ZrO}_{2}$ on the interfacial tension was also observed by Yoneda $e t$ al. ${ }^{21)}$ for this flux system.

Figure 11 shows the summary of the effect of the additions in the $\mathrm{CaO}-\mathrm{SiO}_{2}$ and $\mathrm{CaO}-\mathrm{SiO}_{2}-\mathrm{Al}_{2} \mathrm{O}_{3}$ flux on the interfacial tension, $\gamma_{0}$, obtained from Eq. (2) for each experiment. It was found that, the interfacial tension (i) increased with increasing concentration of basic oxides and fluorides in the flux but (ii) slightly decreased with increasing $\mathrm{Al}_{2} \mathrm{O}_{3}$ content in the flux, and (iii) slightly decreased with increasing $\mathrm{ZrO}_{2}$ content in the range of $\mathrm{ZrO}_{2}<5$ mass\% while increased slightly with increasing $\mathrm{ZrO}_{2}$ in the range of $\mathrm{ZrO}_{2}=5-15$ mass $\%$.

\subsection{Interfacial Tension of Industrial Fluxes}

The interfacial tension measurement was carried out for several practical flux compositions. The final flux compositions and the interfacial tensions are given in

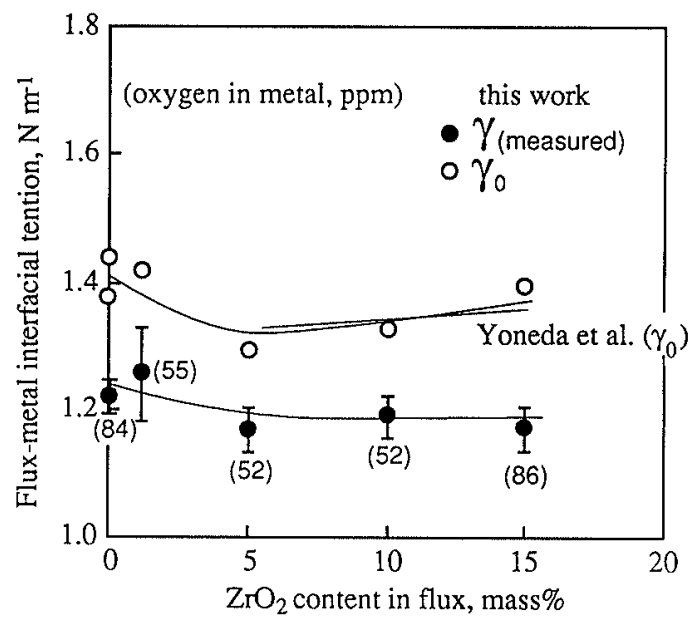

Fig. 10. Effect of $\mathrm{ZrO}_{2}$ in flux on the interfacial tension between liquid iron and flux.

this work: $\mathrm{CaO}-\mathrm{SiO}_{2}-\mathrm{Al}_{2} \mathrm{O}_{3}$ flux, alumina crucible, $1580^{\circ} \mathrm{C}$

Yoneda et al.: $\mathrm{CaO}-\mathrm{SiO}_{2}-\mathrm{Al}_{2} \mathrm{O}_{3}$ flux, alumina crucible, $1580^{\circ} \mathrm{C}$
Table 3. Since only the total fluorine ion was analyzed for these fluxes, the $\mathrm{NaF}$ and $\mathrm{CaF}_{2}$ contents in the fiuxes were simply estimated to be proportional to the molar fraction ratio between $\mathrm{Na}^{+}$and $2 \mathrm{Ca}^{2+}$. As can be seen from the table, $\mathrm{Al}_{2} \mathrm{O}_{3}$ and fluorine were varied for the fluxes Nos. 1-8. About 10 mass $\%$ of $\mathrm{Na}_{2} \mathrm{O}$ was contained in the fluxes ND 1-5 and $\mathrm{NE} 1-4$, and $\mathrm{CaO} / \mathrm{SiO}_{2}$ was also varied in these fluxes. In the fluxes NF 4-8, small amounts of $\mathrm{MgO}$ and $\mathrm{Li}_{2} \mathrm{O}$ were added, and the $\mathrm{CaO} /$ $\mathrm{SiO}_{2}$ ratio was varied. The interfacial tensions obtained for these multicomponent fluxes showed similar trends to those demonstrated in the ternary system described previously, i.e., the interfacial tension slightly increases with increasing fluorine and $\mathrm{Na}_{2} \mathrm{O}$ content in the flux. A slight increase in the interfacial tension with increasing $\mathrm{CaO} / \mathrm{SiO}_{2}$ ratio of flux was observed in these fluxes. The viscosities of several initial fluxes (ND, NE and $\mathrm{NF}, \mathrm{ZrO}_{2}=0$ mass $\%$ ) were measured at $1410^{\circ} \mathrm{C}$ using the rotation method ${ }^{4)}$ and were also given in Table 3.

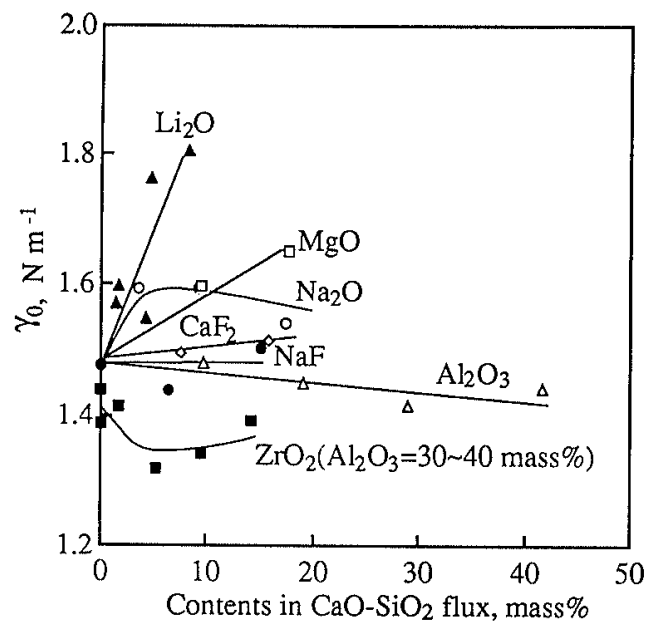

Fig. 11. Influence of additions in $\mathrm{CaO}-\mathrm{SiO}_{2}$ flux $(\% \mathrm{CaO} /$ $\% \mathrm{SiO}_{2}=\mathrm{I}$ ) on the interfacial tension between liquid iron and flux at $1580^{\circ} \mathrm{C}$.

Table 3. Flux compositions, viscosities and interfacial tensions between flux and molten iron.

\begin{tabular}{|c|c|c|c|c|c|c|c|c|c|c|c|c|c|c|}
\hline \multirow{2}{*}{ Flux } & \multicolumn{9}{|c|}{ flux compositions } & \multirow{2}{*}{$\begin{array}{l}\text { oxygen activity } \\
\text { in metal, a }\end{array}$} & \multirow{2}{*}{$\begin{array}{l}\text { flux } \\
\text { viscosity* } \\
\text { poise }\end{array}$} & \multirow{2}{*}{$\begin{array}{l}\text { flux } \\
\text { density } \\
10^{3} \mathrm{~kg} \mathrm{~m}^{-3}\end{array}$} & \multicolumn{2}{|c|}{ interfacial tension } \\
\hline & $\mathrm{CaO}$ & $\mathrm{SiO}_{2}$ & $\mathrm{Al}_{2} \mathrm{O}_{3}$ & $\mathrm{Na}_{2} \mathrm{O}$ & $\begin{array}{l}\mathrm{ZrO}_{2} \\
\text { ass } \%\end{array}$ & $\mathrm{~F}^{-}$ & $\mathrm{FeO}$ & $\mathrm{MgO}$ & $\mathrm{Li}_{2} \mathrm{O}$ & & & & $\begin{array}{c}\gamma \\
\mathrm{Nm}^{-1}\end{array}$ & $\begin{array}{c}\gamma_{0} \\
\mathrm{Nm}^{-1}\end{array}$ \\
\hline No.1 & 42.0 & 37.7 & 1.9 & 6.4 & 10.1 & 3.1 & 0.54 & & & 0.0032 & & 2.527 & 1.377 & 1.481 \\
\hline No.2 & 40.5 & 36.4 & 1.8 & 7.6 & 9.7 & 4.8 & 0.36 & & & 0.0028 & & 2.499 & 1.325 & 1.416 \\
\hline No. 3 & 39.7 & 34.7 & 1.6 & 8.8 & 11.0 & 4.4 & 0.27 & & & 0.0039 & & 2.503 & 1.334 & 1.454 \\
\hline No.4 & 37.6 & 33.2 & 1.7 & 10.4 & 11.7 & 6.1 & 0.27 & & & 0.0025 & & 2.480 & 1.330 & 1.413 \\
\hline No. 5 & 40.6 & 36.5 & 5.5 & 5.0 & 9.5 & 3.2 & 0.36 & & & 0.0026 & & 2.556 & 1.351 & 1.435 \\
\hline No.6 & 39.4 & 35.4 & 5.3 & 7.3 & 9.1 & 3.5 & 0.54 & & & 0.0024 & & 2.532 & 1.338 & 1.418 \\
\hline No.7 & 38.0 & 33.7 & 5.1 & 7.5 & 10.7 & 4.0 & 0.45 & & & 0.0040 & & 2.538 & 1.348 & 1.471 \\
\hline No.8 & 36.2 & 32.8 & 4.8 & 10.1 & 10.4 & 6.5 & 0.36 & & & 0.0026 & & 2.489 & 1.332 & 1.418 \\
\hline ND-1 & 28.4 & 45.1 & 0.8 & 8.6 & 12.7 & 4.9 & 0.91 & & & 0.0036 & 6.80 & 2.442 & 1.360 & 1.474 \\
\hline ND-2 & 34.0 & 41.1 & 0.5 & 9.1 & 11.2 & 4.7 & 0.63 & & & 0.0029 & 3.10 & 2.456 & 1.388 & 1.481 \\
\hline ND-3 & 38.8 & 36.0 & 0.5 & 9.0 & 11.7 & 4.8 & 0.36 & & & 0.0036 & 1.80 & 2.489 & 1.379 & 1.493 \\
\hline ND-4 & 40.8 & 34.6 & 0.5 & 9.5 & 10.7 & 5.2 & 0.27 & & & 0.0056 & 1.10 & 2.486 & 1.408 & 1.569 \\
\hline ND-5 & 45.9 & 31.9 & 0.5 & 8.6 & 10.0 & 4.6 & 0.27 & & & 0.0037 & 0.90 & 2.518 & 1.437 & 1.554 \\
\hline$N E-1$ & 36.6 & 32.6 & 1.3 & 12.3 & 11.9 & 6.7 & 0.36 & & & 0.0035 & 0.85 & 2.459 & 1.292 & 1.403 \\
\hline $\mathrm{NE}-2$ & 45.7 & 32.3 & 0.5 & 9.1 & 8.9 & 5.6 & 0.27 & & & 0.0066 & 0.85 & 2.497 & 1.456 & 1.639 \\
\hline NE-3 & 35.2 & 30.6 & 10.6 & 11.3 & 9.5 & 5.8 & 0.27 & & & 0.0032 & 2.30 & 2.519 & 1.395 & 1.498 \\
\hline NE-4 & 41.4 & 37.0 & 2.0 & 5.8 & 10.1 & 2.9 & 0.36 & 1.6 & & 0.0032 & 2.30 & 2.540 & 1.398 & 1.501 \\
\hline$N F-5$ & 37.0 & 31.4 & 8.9 & 2.4 & 10.5 & 7.0 & 0.27 & 1.4 & 2.1 & 0.0032 & 2.00 & 2.563 & 1.260 & 1.363 \\
\hline$N F-6$ & 40.8 & 36.4 & 3.3 & 3.4 & 7.4 & 3.7 & 0.45 & 0.6 & 0.0 & 0.0059 & 4.00 & 2.542 & 1.268 & 1.438 \\
\hline $\mathrm{NF}-7$ & 36.3 & 36.6 & 5.2 & 2.7 & 10.2 & 3.3 & 0.36 & 0.4 & 0.9 & 0.0045 & 6.00 & 2.553 & 1.287 & 1.423 \\
\hline NF-8 & 33.9 & 42.5 & 5.1 & 2.7 & 7.1 & 3.7 & 0.90 & 1.0 & 0.0 & 0.0066 & 8.00 & 2.519 & 1.223 & 1.406 \\
\hline
\end{tabular}

* viscosity values at $1410^{\circ} \mathrm{C}$ for initial flux 


\section{Prediction of Interfacial Tension}

In order to obtain an empirical relation between interfacial tension and flux composition, the following relation was derived on the assumption of the additivity of the contribution of each component in the flux and metal oxygen to the interfacial tension.

$$
\gamma=\sum_{i=1}^{n} A_{i} X_{i}+\sum_{i=1}^{n-1} \sum_{j=i+1}^{n} B_{i}^{j} X_{i} X_{j}-0.324 \ln \left(1+116 a_{\mathrm{o}}\right)
$$

where, $A_{i}$ : the interfacial tension factor of component $i$ in the flux, $\mathrm{Nm}^{-1}$,

$B_{i}^{i}$ : the interaction factor of the interfacial tension between component $i$ and $j$ in the flux, $\mathrm{N} \mathrm{m}^{-1}$, and

$X_{i}$ : molar fraction of component $i$ in the flux.

The values of $A_{i}$ and $B_{i}^{j}$ are determined by the trial and error method from the observed results of present study and are shown in Tables 4 and 5. Larger interfacial tension factors were obtained for the strong basic components in the fluxes and the minus values were obtained for the interaction factors of the interfacial tension. The standard deviation, as seen in Fig. 12a), between the value calculated by Eq. (3) and the observed was $0.047 \mathrm{~N} \mathrm{~m}^{-1}$.

In Fig. 12b), the same comparison of interfacial tensions between molten iron and fluxes was made for the experimental results obtained by Shinozaki et al., ${ }^{16)}$ Gaye et al., ${ }^{17)}$ Bretonnet et al., ${ }^{22}$ and Riboud and Lucas $^{23)}$ for which oxygen contents in the metal were reported. The standard deviation was increased to 0.074 $\mathrm{Nm}^{-1}$. Although there exists some overestimation of the interfacial tension for the fluxes containing more than 15 mass $\% \mathrm{Na}_{2} \mathrm{O}$, the values for $\mathrm{CaO}-\mathrm{SiO}_{2}-\mathrm{CaF}_{2}-$

Table 4. Interfacial tension factors, $A_{i}$, standard free energy changes of formation an oxide, $\Delta G_{i}^{0}$, surface tension factors, ${ }^{0} \sigma_{i}$, ion-oxygen attraction, $I_{i}(=$ $\left.Z / r_{i} r_{0}\right)$, interaction energies with iron ion in flux, $\alpha_{i} \mathrm{Fe}^{++}$.

\begin{tabular}{|c|c|c|c|c|c|}
\hline $\mathrm{i}$ & $\underset{\mathrm{N} \mathrm{m}^{-1} \mathrm{~mol}^{-1}}{\mathrm{~A}_{\mathrm{i}}}$ & $\begin{array}{c}\Delta \mathrm{G}_{\mathrm{i}}^{0} \\
\mathrm{~kJ} \mathrm{~mol}^{-1}\end{array}$ & $\begin{array}{c}\mathrm{S}^{\mathrm{i}} \\
\mathrm{N} \mathrm{m} \\
\mathrm{mol}^{-1} \mathrm{~mol}^{-1}\end{array}$ & $\mathrm{I}_{\mathrm{i}}$ & $\begin{array}{c}\alpha_{i}^{\mathrm{Fe}^{++}} \\
\mathrm{kJ} \mathrm{mol}^{-1}\end{array}$ \\
\hline $\begin{array}{l}\mathrm{CaO} \\
\mathrm{SiO}_{2} \\
\mathrm{Al}_{2} \mathrm{O}_{3} \\
\mathrm{MgO} \\
\mathrm{Li}_{2} \mathrm{O} \\
\mathrm{Na}_{2} \mathrm{O} \\
\mathrm{CaF}_{2} \\
\mathrm{NaF}_{2} \\
\mathrm{ZrO}_{2}\end{array}$ & $\begin{array}{l}1.868 \\
1.477 \\
1.561 \\
2.380 \\
4.190 \\
2.870 \\
1.980 \\
2.360 \\
1.910\end{array}$ & $\begin{array}{c}-433.6 \\
-290.3 \\
-360.6 \\
-350.4 \\
-316.5 \\
-85.3 \\
-. \\
- \\
-376.4\end{array}$ & $\begin{array}{c}0.747 \\
0.293 \\
0.759 \\
0.750 \\
0.430 \\
0.366 \\
0.280 \\
-- \\
\ldots\end{array}$ & $\begin{array}{c}0.70 \\
2.44 \\
1.66 \\
0.95 \\
0.50 \\
0.36 \\
-- \\
-- \\
--\end{array}$ & $\begin{array}{c}-31.35 \\
-41.80 \\
-1.76 \\
33.44 \\
-- \\
19.23\end{array}$ \\
\hline
\end{tabular}

Table 5. Interaction interfacial factors, $B_{i}^{j}, \mathrm{Nm}^{-1} \mathrm{~mol}^{-1}$

\begin{tabular}{lccccccccc}
\hline $\mathrm{i} \backslash \mathrm{j}$ & $\mathrm{CaO}$ & $\mathrm{SiO}_{2}$ & $\mathrm{Al}_{2} \mathrm{O}_{3}$ & $\mathrm{MgO}$ & $\mathrm{Na}_{2} \mathrm{O}$ & $\mathrm{Li}_{2} \mathrm{O}$ & $\mathrm{ZrO}_{2}$ & $\mathrm{NaF}$ & $\mathrm{CaF}_{2}$ \\
$\mathrm{CaO}$ & - & -0.98 & -1.22 & -0.90 & -0.40 & -0.40 & -1.00 & -3.45 & -0.50 \\
$\mathrm{SiO}_{2}$ & -0.98 & - & -0.20 & -0.39 & -1.20 & -0.40 & -0.70 & -0.50 & -0.10 \\
$\mathrm{Al}_{2} \mathrm{O}_{3}$ & -1.22 & -0.20 & - & -15.0 & -3.50 & -14.5 & -2.60 & -7.00 & -1.75 \\
$\mathrm{MgO}$ & -0.90 & -0.39 & -15.0 & - & -3.00 & -18.0 & 0 & -12.0 & -3.05 \\
$\mathrm{Na}_{2} \mathrm{O}$ & -0.40 & -1.20 & -3.50 & -3.00 & - & -14.5 & -0.50 & -4.00 & -3.45 \\
$\mathrm{Li}_{2} \mathrm{O}$ & -0.40 & -0.40 & -14.5 & -18.0 & -14.5 & - & -1.00 & -18.0 & -18.0 \\
$\mathrm{ZrO}_{2}$ & -1.00 & -0.70 & -2.60 & 0 & -0.50 & -1.00 & - & -6.00 & -2.00 \\
$\mathrm{NaF}^{2}$ & -3.45 & -0.50 & -7.00 & -12.0 & -4.00 & -18.0 & -6.00 & - & -3.10 \\
$\mathrm{CaF}_{2}$ & -0.50 & -0.10 & -1.75 & -3.05 & -3.45 & -18.0 & -2.00 & -3.10 & - \\
\hline
\end{tabular}

$\mathrm{Na}_{2} \mathrm{O}-\mathrm{Al}_{2} \mathrm{O}_{3}$ flux reported by Gaye et al. are in general agreement with the predictions using Eq. (3). For the ternary system $\mathrm{CaO}-\mathrm{CaF}_{2}-\mathrm{Al}_{2} \mathrm{O}_{3}$, the measurements by Riboud et al. agree well with Eq. (3) if $\mathrm{CaF}_{2}$ in the fluxes is below 70 mass \%. In spite of a larger scatter in the values for fluxes with more than 15 mass $\% \mathrm{MgO}$ and more than 30 mass $\% \mathrm{CaF}_{2}$, there is a general agreement with those observed for the $\mathrm{CaO}-\mathrm{SiO}_{2}-\mathrm{CaF}_{2}-\mathrm{Na}_{2} \mathrm{O}-$ $\mathrm{Li}_{2} \mathrm{O}-\mathrm{MgO}-\mathrm{Al}_{2} \mathrm{O}_{3}$ system reported by Shinozaki et al. The variation of the predicted interfacial tension compares reasonably well with those measured by Bretonnet et al. for the $\mathrm{CaO}-\mathrm{SiO}_{2}-\mathrm{Al}_{2} \mathrm{O}_{3}$ system using slag lens method. But the interfacial tensions reported in their study are, in general, smaller than the measurements obtained in the present investigation.

The physical concepts of the interfacial tension factors, $A_{i}$, and interaction interfacial factors, $B_{i}^{j}$, are not yet clear at present stage. A more extensive study on the multicomponent system is considered to be necessary in the future to upgrade the accuracy of these factors. It is instructive to examine the correlation of these factors with other properties of the flux to establish their physical
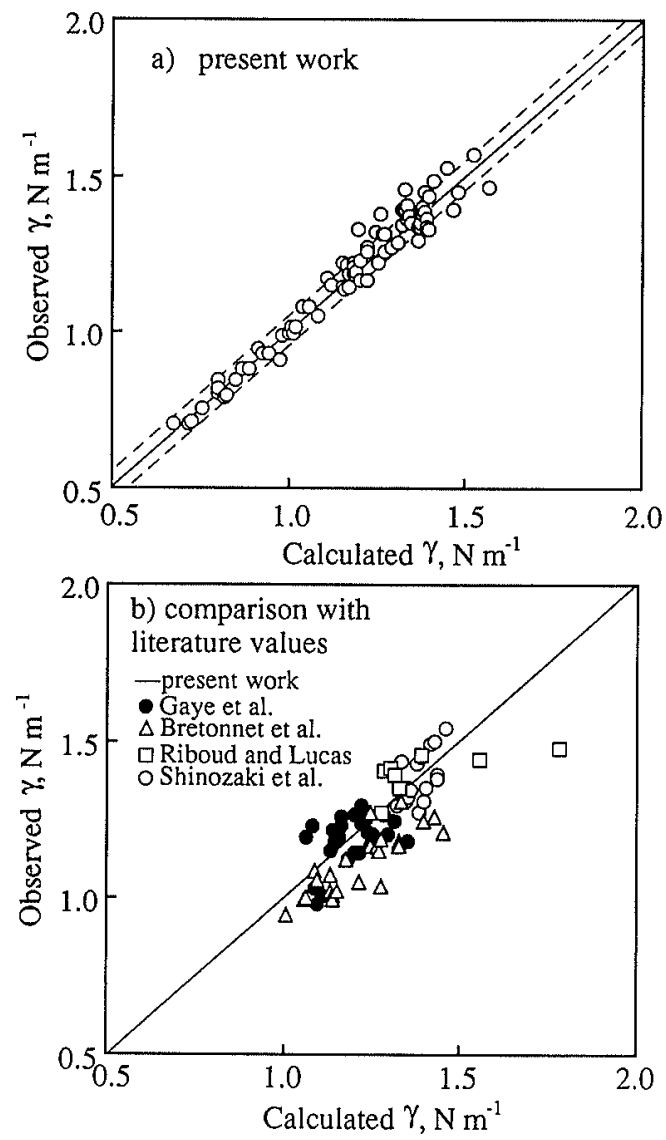

Fig. 12. Calculated $v s$. observed interfacial tension values for flux-iron system.

present work: $\mathrm{CaO}-\mathrm{SiO}_{2}-\mathrm{NaF}-\mathrm{CaF}_{2}-\mathrm{Al}_{2} \mathrm{O}_{3}-\mathrm{Na}_{2} \mathrm{O}-$ $\mathrm{MgO}-\mathrm{Li}_{2} \mathrm{O}-\mathrm{ZrO}_{2}, 1580^{\circ} \mathrm{C}$, zirconia crucible Gaye et al:: $\mathrm{CaO}-\mathrm{SiO}_{2}-\mathrm{Al}_{2} \mathrm{O}_{3}-\mathrm{Na}_{2} \mathrm{O}-\mathrm{CaF}_{2}$, alumina crucible, $1600^{\circ} \mathrm{C}$

Bretonnet et al.: $\mathrm{CaO}-\mathrm{SiO}_{2}-\mathrm{Al}_{2} \mathrm{O}_{3}$, lens method, $1600^{\circ} \mathrm{C}$

Riboud and Lucas: $\mathrm{CaO}-\mathrm{Al}_{2} \mathrm{O}_{3}-\mathrm{CaF}_{2}$, alumina crucible, $1600^{\circ} \mathrm{C}$

Shinozaki et al: $\mathrm{CaO}-\mathrm{SiO}_{2}-\mathrm{Al}_{2} \mathrm{O}_{3}-\mathrm{Na}_{2} \mathrm{O}-\mathrm{Li}_{2} \mathrm{O}-$ $\mathrm{CaF}_{2}$, alumina crucible, $1600^{\circ} \mathrm{C}$ 

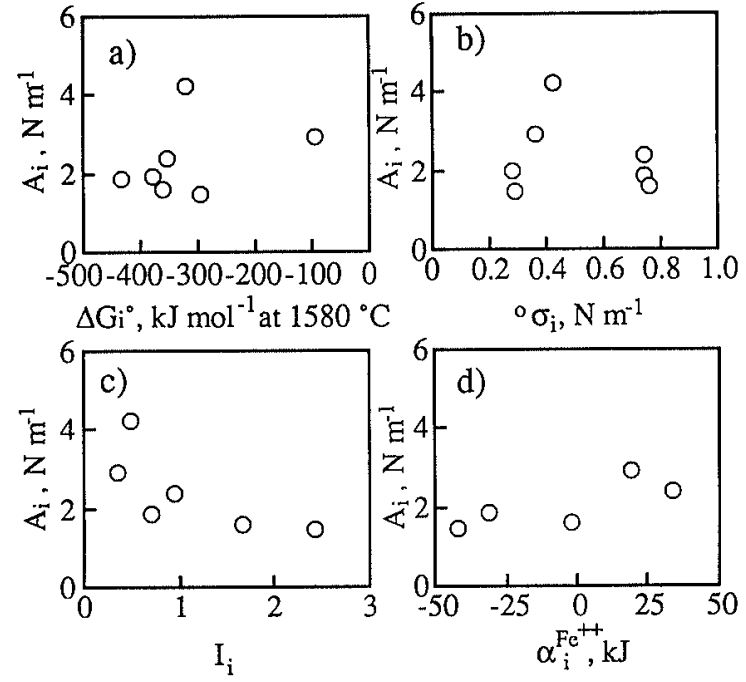

Fig. 13. Relations of interfacial tension factors, $A_{i}$, with standard free energy changes of oxide formation (a), $\Delta G_{i}^{0}$, surface tension factors (b), ${ }^{0} \sigma_{i}$, ion-oxygen attraction (c), $I_{i}$, and interaction energies with iron ion in flux $(\mathrm{d}), \alpha_{i}^{\mathrm{Fc}^{++}}$
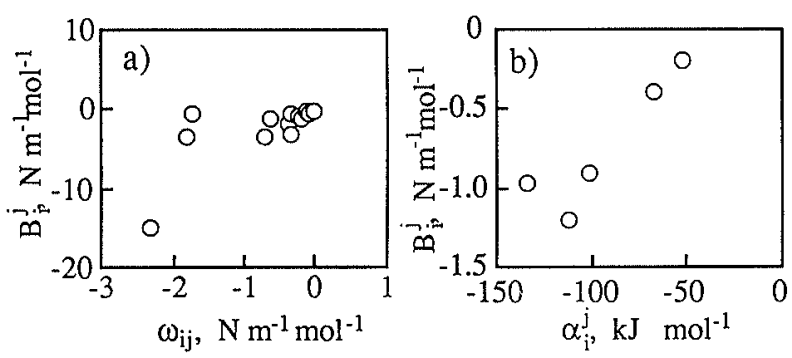

Fig. 14. Relations of interaction interfacial factors, $B_{i}^{j}$ with interaction surfacial factors (a), $\omega_{i j}$, and interaction energies between cations $(\mathrm{b}), \alpha_{i}^{j}$.

meaning. Figure 13a) shows a slight increasing trend of interfacial tension factors with standard free energy changes $^{24)}$ for a pure solid oxide formation from one mole of oxygen gas and pure solid metal elements at $1580^{\circ} \mathrm{C}$. Any significant trend can not be seen in Fig. 13b) between the interfacial tension factors and the surface tension factors. ${ }^{25}$ ) Figures 13c) and 13d), respectively, show the decreasing trend of the interfacial factors of a pure component with the ion-oxygen attraction $^{26)}$ and the increasing trend of those with interaction energies with iron ion in the fluxes. ${ }^{27)}$ For the interaction interfacial factors, as seen in Figs. 14a) and 14b), respectively, there was an increasing trend of interaction interfacial factors with (a) interaction surface factors $^{25)}$ and (b) interaction energies between cations. ${ }^{27)}$

Figures 15 and 16, respectively, show the relations of the interfacial tension, $\gamma_{0}$, between molten iron and fluxes with optical basicity ${ }^{28)}$ and with the viscosity of the fluxes. An increasing tendency of the interfacial tension with optical basicity of the fluxes and a slightly decreasing tendency of those with viscosity of the fluxes were observed.

\section{Conclusions}

The effects of (a) $\mathrm{NaF}, \mathrm{CaF}_{2}, \mathrm{Al}_{2} \mathrm{O}_{3}, \mathrm{Na}_{2} \mathrm{O}, \mathrm{MgO}$, $\mathrm{Li}_{2} \mathrm{O}$ and $\mathrm{ZrO}_{2}$ in $\mathrm{CaO}-\mathrm{SiO}_{2}$ and $\mathrm{CaO}-\mathrm{SiO}_{2}-\mathrm{Al}_{2} \mathrm{O}_{3}$

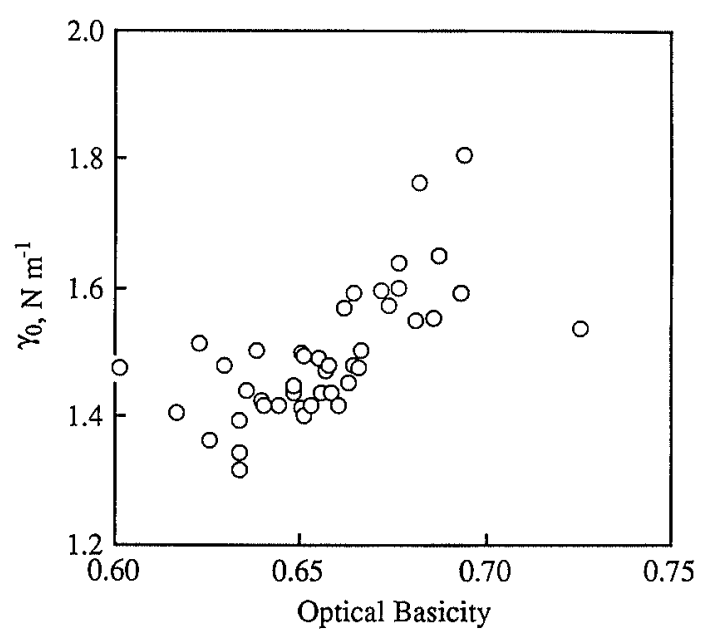

Fig. 15. Relation between optical basicity of flux and interfacial tension.

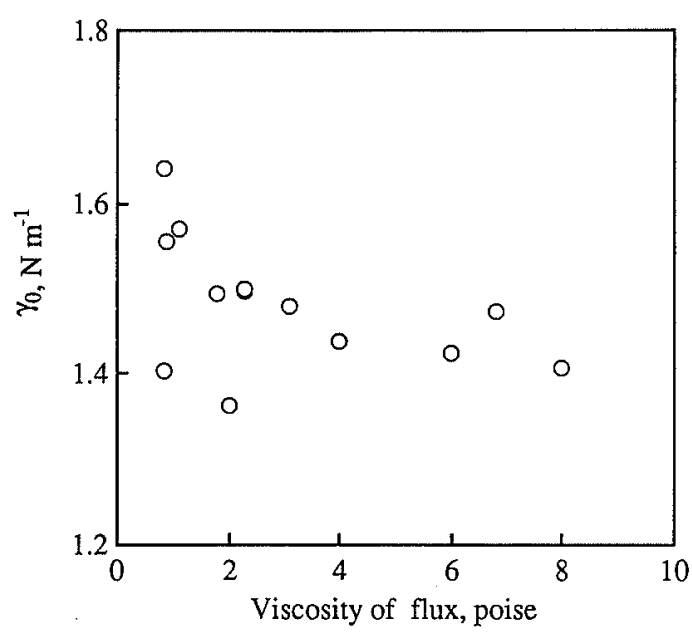

Fig. 16. Relation between viscosity of flux at $1410^{\circ} \mathrm{C}$ and the interfacial tension between liquid iron and flux at $1580^{\circ} \mathrm{C}$.

fluxes and (b) oxygen in the metal on the interfacial tension between molten iron and fluxes were investigated at $1580^{\circ} \mathrm{C}$ by the sessile drop method using zirconia or alumina crucibles. It was found that the interfacial tension between $35 \mathrm{CaO}-35 \mathrm{SiO}_{2}-30 \mathrm{Al}_{2} \mathrm{O}_{3}$ flux and liquid iron with various oxygen content could be expressed by the following equation.

$$
\gamma_{0}-\gamma=0.324 \ln \left(1+116 a_{0}\right)
$$

where $a_{\mathrm{O}}$ is the activity of oxygen in liquid iron, and $\gamma_{0}$ is a hypothetical interfacial tension at infinitesimally low $a_{\mathrm{O}}$.

In the examination of the variation of the interfacial tension with flux composition, the effect of oxygen in the melt was taken into account. The variation of the interfacial tension with flux composition has shown up the varying effects of some individual components of these flux. Minor changes in the interfacial tension were observed with varying $\mathrm{ZrO}_{2}$ content in the fluxes. A slight decrease of the interfacial tension was found as the $\mathrm{Al}_{2} \mathrm{O}_{3}$ content in flux increased. The interfacial tension was markedly increased with the additions of $\mathrm{Na}_{2} \mathrm{O}, \mathrm{MgO}$ and $\mathrm{Li}_{2} \mathrm{O}$ to the fluxes, and slightly increased with the 
additions of the fluorides $\mathrm{NaF}$ and $\mathrm{CaF}_{2}$ to the fluxes. An empirical relation, Eq. (3), for the prediction of the interfacial tension was derived from considering the effect of the flux components and oxygen content in the melt.

\section{Acknowledgements}

The authors wish to thank Mr. T. Matsuyama, Nippon Steel Metal Products Co., Ltd., for providing the several types of fluxes and chemical analyses of the fluxes. This work was sponsored by The Iron and Steel Institute of Japan and Nippon Steel Corporation.

\section{REFERENCES}

1) H. Sun, R. Ito, K. Nakashima and K. Mori: Tetsu-to-Hagané, 81 (1995), 888.

2) K. Nakajima: Tetsu-to-Hagané, 80 (1994), 593.

3) H. Bloom and B. W. Burrows: Proc. First Australian Conf. Electrochem., Pergamon Press, New York, (1963), 882.

4) T. Matsuyama: private communication.

5) K. Ogino, S. Hara, R. Mitsuwa and K. Kimoto: Tetsu-to-Hagané, 65 (1979), 2012.

6) K. Mukai, T. Kato and H. Sakao: Tetsu-to-Hagané, 59 (1973), 55

7) N. Shinozaki, T. Kurashige, K. Mori and Y. Kawai: J. Jpn. Inst. Met., 46 (1982), 60.

8) S. I. Popel and G. F. Konovalov: Izv, V.U.Z. Chernaya. Metall., 8 (1959), 3.

9) The Japan Society for the Promotion of Science, The 19th Comm. on Steelmaking: Steelmaking Data Sourcebook, Revised Edition, Gordon and Breach Science Publisher, Tokyo, (1988), 273.
10) G. R. Belton: Metall. Trans. B, 7B (1976), 35.

11) Handbook of Physico-chemical Properties at High Temperatures, ed. by Y. Kawai and Y. Shiraishi, ISIJ, Tokyo, September, (1988).

12) K. Ogino, N. Nogi and C. Hosoi: Tetsu-to-Hagané, 69 (1983) 1989.

13) I. Jimbo, A. Sharan and A. W. Cramb: Steelmaking Conf. Proc., 76 (1993), 485

14) A. Kasama, A. McLean, W. A. Miller, Z. Morita and M. J. Ward: Can. Metall. Q., 22 (1983), 19.

15) P. P. Evseev and A. F. Filippov: Izv. VUZ., 6 (1965), 72.

16) N. Shinozaki, H. Fujiike, K. Mori and Y. Kawai: Tech. Rep. Kyushu Univ., 62 (1989), 575.

17) H. Gaye, L. D. Lucas, M. Olette and P. V. Riboud: Can. Metall. Q., 23 (1984), 179

18) K. Ogino and S. Hara: Tetsu-to-Hagané, 63 (1977), 2141.

19) T. El Gammal and P. Stracke: Proc. 3rd Int. Conf. on Molten Slags and Fluxes, Glasgow, 1988: Inst. Met., London, (1989), 207.

20) A. Adachi, K. Ogino, T. Suetaki and T. Saito: Tetsu-to-Hagané 51 (1965), 1857.

21) N. Yoneda, H. Sun and K. Mori: CAMP-ISIJ, 8 (1995), 1110.

22) J. L. Bretonnet, L. D. Lucas and M. Olette: C. R. Hebd. Seances Acad. Sci., Paris 280C (1975), 1169 and 285 (1977), 45.

23) P. V. Riboud and L. D. Lucas: Can. Metall. Q., 20 (1981), 199.

24) Handbook of Iron and Steelmaking, ed. by ISIJ, Maruzen, Tokyo, (1983).

25) K. Nakajima: Tetsu-to-Hagané, 80 (1994), 599.

26) R. C. Ward: An Introduction to the Physical Chemistry of Iron and Steelmaking, Edward Arnold Ltd., London, (1962)

27) S. Ban-ya: ISIJ Int., 33 (1993), 2.

28) J. A. Duffy: Ironmaking Steelmaking, 17 (1990), 411

29) H. Sun, N. Yoneda, K. Nakashima and K. Mori: Tetsu-toHagané, 83 (1997), 1. 